Jurnal Kajian Akuntansi, Vol. 4 No. 1 2020, 40-51

e2579-9991, p2579-9975

http://jurnal.unswagati.ac.id/index.php/jka

\title{
DETERMINANT OF VILLAGE COMMUNITY WELFARE IMPROVEMENT
}

\author{
Purwanto $^{1}$, Hasna Safira ${ }^{2}$ \\ ${ }^{1}$ Faculty of Economics and Business UNJANI \\ ${ }^{2}$ Information Systems Binus University \\ purwanto875875@gmail.com; hasna.safira@binus.ac.id
}

\begin{abstract}
Village Fund (DD) has been allocated by Central Government since 2015, with a budget of Rp.20.80 trillion, and in 2020, DD is budgeted to be Rp72 trillion, experiencing a significant increase in 5 years. Priority for DD use according to the rules (Permendesa PDTT, No.11 / 2019) must provide as much benefit to the village community in the form of: a. life quality improvement; $b$. welfare improvement; $c$. poverty alleviation; and $d$. public services improvement (health, education, and social). The research was conducted in Cimerang Village, Padalarang Subdistrict, West Bandung Regency and aimed at analyzing the influence of DD Financial Management Accountability, Village Policy, and Village Institutions to the Improvement of Village Community Welfare This research used quantitative methods, where primary data was obtained from questionnaires of 135 respondents from the local village community and the Village Institution. The results indicated that three independent variables partially had a significant positive effect on improving the village community welfare. With the potential of vast agricultural land, including horticulture and animal husbandry, the creation of Village-Owned Enterprises (BUMDes) is a priority scale for Cimerang Village in the efforts of village independence, and from the results of efforts can be used in improving the quality of health and education, for example the establishment of the Polyclinic that provides health care is more diverse than Posyandu, the construction of a high school equivalent. Its influence is very meaningful for improving the welfare of the local community.
\end{abstract}

Keywords: Accountability; BUMDes; Village fund

\section{Abstrak}

Dana Desa (DD) dialokasikan oleh Pemerintah Pusat sejak tahun 2015, dengan anggaran Rp 20,80 triliun, dan di tahun 2020 dianggarkan menjadi Rp 72 triliun, mengalami kenaikan signifikan dalam kurun waktu 5 tahun. Prioritas penggunaan DD sesuai aturan (Permendesa PDTT, No.11/2019) harus memberikan manfaat sebesar besarnya bagi masyarakat desa berupa: a. peningkatan kualitas hidup; b. peningkatan kesejahteraan; $c$. penanggulangan kemiskinan; dan $d$. peningkatan pelayanan publik (kesehatan, pendidikan, dan sosial). Penelitian ini dilakukan di Desa Cimerang, Kecamatan Padalarang, Kabupaten Bandung Barat, dengan tujuan untuk menganalisis pengaruh Akuntabilitas Pengelolaan Keuangan DD, Kebijakan Desa, dan Kelembagaan Desa terhadap Peningkatan Kesejahteraan Masyarakat Desa. Penelitian ini menggunakan metode kuantitatif, data primer yang diperoleh dari penyebaran kuesioner diperoleh dari 135 responden masyarakat desa setempat dan Perangkat Lembaga Desa. Hasil dari penelitian ini menunjukkan bahwa secara parsial, ketiga variabel independen berpengaruh positif signifikan terhadap Peningkatan Kesejahteraan Masyarakat Desa. Dengan potensi lahan pertanian yang luas, temasuk di dalamnya holtikultura, dan peternakan, penciptaan Badan Usaha Milik Desa (BUMDes) merupakan skala prioritas bagi Desa Cimerang dalam upaya kemandirian Desa, dan dari hasil usaha dapat digunakan dalam peningkatan kualitas kesehatan serta pendidikan, misalnya pendirian Poliklinik yang memberikan pelayan kesehatan lebih beragam dibandingkan Posyandu, pembangunan sekolah setara menengah atas. Pengaruhnya sangat berarti bagi peningkatan kesejahteraan masyarakat setempat.

Katakunci: Akuntabilitas; BUMDes; Dana desa

Cronicle of Article: Received (April 2020); Revised (May 2020); and Published (June 2020).

C2020 Jurnal Kajian Akuntansi Lembaga Penelitian Universitas Swadaya Gunung Jati.

Profile and corresponding author: Purwanto is a lecturer from Faculty of Economics and Business UNJANI and Hasna Safira is from of Information Systems of Binus University.

Corresponding Author: purwanto875875@gmail.com.

How to cite this article: Purwanto \& Safira, H. (2020). Determinant of Village Community Welfare Improvement. Jurnal Kajian Akuntansi. Jurnal Kajian Akuntansi, 4 (1), 40-51. 


\section{INTRODUCTION}

Village Funds (DD) are funds sourced from the State Revenue and Expenditure Budget (APBN) which are intended for villages that are transferred through the district / city Regional Revenue and Expenditure Budget (APBD) and are used to finance government administration, development implementation, community development, and community empowerment (PMK, No.205 / PMK.07 / 2019). Priority for DD use according to the rules (Permendesa PDTT, No.11 / 2019) must provide as much benefit to the village community in the form of: a. improvement of quality of life; $b$. welfare improvement; c. poverty alleviation; and $\mathrm{d}$. improvement of public services (health, education, and social). With the implementation of these two regulations, DD has proven to have produced facilities / infrastructure that are beneficial to the community, such as the construction of village roads, clean water connections, construction of schools and health as well as the development of tourist areas through BUMDes (VillageOwned Enterprises). The key to success for the welfare of the community in developing villages is the strong touch of initiation, innovation, creation and cooperation between village officials and the community in realizing what they aspire to be. Village development is not possible for village officials themselves, but they need support, initiative, and an active role from the community (Ministry of Finance of the Republic of Indonesia, 2017).

The DD program began in 2015 with a budget of Rp20.80 trillion. In 2016, DD increased to Rp46.98 trillion; in 2017 and 2018 each budgeted at $\mathrm{Rp} 60$ trillion; then in 2019 the amount of the budget is Rp70 trillion and in 2020 an increase of 2.86 percent from the previous year, to $\mathrm{Rp} 72$ trillion (Ministry of Finance, 2020).

Kutuh Village in South Badung, Bali, known as an independent village, is one example of successful in DD management; whereas, a few years ago it was classified as a poor village. The community-based process development; the village is not an object, but the village is the subject of development. Villages must be good at exploring themselves. Currently, it has 9 business units including Village Credit Institutions, Tourism Areas, Transportation and Construction Services Units. The village invited 160 family heads to become entrepreneurs of the tourism sector by selling around the tourist area (Fiansyah, Rahmat, 2019). Another example is Pujon Kidul Village, Malang, in managing village funds used to establish Village-Owned Enterprises (BUMDes) that have succeeded in juggling this village into a tourist site, such as rice field cafe, harvest picking tours of apple agriculture, vegetable tourism, milking, that draws thousands of visitors every day; giving an impact on economic activity of the community, reducing unemployment (Times Indonesia, 2019). Ponggok Village, Klaten Regency, Central Java is one example of other villages that have successfully managed the village funds; one of them is used for the development of BUMDes, which is able to boost community income in the village (Deny, Septian, 2017).

The object selection for this research was carried out in Cimerang Village, Padalarang District, West Bandung Regency, with an emphasis on the field of community welfare, including the fields of health, education, and employment. The current condition of the village is still far behind compared to others; in terms of health facilities, it does not have a community Health center (Puskesmas), maternity clinics and pharmacies, but there is only Maternal \& Child Health Centre (Posyandu). For school buildings, it is not available for high school / equivalent level. In terms of employment, the agriculture and trade sectors are still relatively small, respectively at $27.80 \%$ and $1.50 \%$, and the 
unemployment rate is $14.37 \%$ (BPS KBB, 2018).

The lack of successful management of DD in Cimerang village has become a research gap, when compared to other villages above with success. The independent variables analyzed are DD Financial Management Accountability, Village Policy, and Village Institutions.

\section{LITERATURE REVIEW}

\section{Village Community Welfare}

Todaro (2006: 250) and Nasution et. al (2017) The welfare of the middle to lower class can be represented from the level of community life which is characterized by poverty alleviation, better health, higher education level, and increased community productivity. This is in line with Dura (2016) and Fourchard (2011) that community welfare is a social, material, and spiritual procedure and livelihood that is encompassed by an increased sense of safety, decency, and tranquility for every citizen to make efforts to fulfill physical, spiritual, and social needs for themselves, including rural communities. The Central Statistics Agency (2018) stated that the benchmarks for public welfare are health, education, and employment.

\section{Village Fund}

According to PMK RI (No. 205/PMK.07/2019), the allocation of DD is based on consideration of population, poverty, area, and geographical difficulty. DD has an important role in village development facilities, community empowerment, and can finance all other matters (Winarsih \& Kristianti, 2017; Robinson, 2013).

\section{Relationship Between DD Financial Management Accountability, Village Policy, and Village Institutions to Improvement of Village Community Welfare}

Government Regulation No. 60 (2014) Performance Accountability System Government Agencies must implement Good Governance, where the benefits include restoring and maintaining community trust in the organization; encourage organizational transparency and responsiveness; encourage community participation; make the organization more able to operate efficiently, effectively, economically, and responsively to the aspirations of the community and its environment; encourage improvement in the quality of services to the community (Waluyo, 2007: 182). If Good Governance is implemented consistently and responsibly, it will have implications for improving welfare of the village community (Wibisono \& Purnomo, 2017; Syafi'i et.,al., 2018). Likewise, village policy in its implementation takes the form of village regulations, where the responsibility for village autonomy remains under the authority and supervision of the district / city government (Temenggung, 2014; Aziz, 2016).

RI Law. No. 6 (2014) Village Institution is the representative of village population over a democratically determined territory; has important benefits, including increasing the ability of villages to provide services to local communities, improving village infrastructure, making independent planning based on available allocation funds, making it more possible for the bottom-up planning process, and opening up greater possibilities for communities to exercise control over their implementation; in turn, can improve the welfare of village communities.

\section{Hypothesis}

From the explanation above, the research hypotheses are:

H1. DD Financial Management Accountability significantly influences the improvement of Village Community Welfare

H2. Village Policy significantly influences the improvement of Village Community Welfare

H3. Village Institution significantly influences the improvement of Village Community Welfare 


\section{Previous Research}

Savitri, et. al. (2019) conducted a study of accountability and transparency of village funds management in Riau Province of Indonesia. In particular, it focuses the analysis on the implementation, reporting, planning, and accountability stages, to review the community participation in management of village fund and the obstacles to its implementation; with 31 respondents consisted of chief of the villages, village secretaries and village treasurers of coastal villages. Results showed that all stages of village management were in accordance with the existing provisions. Some obstacles were found in the program implementation. These include the lack of human resources, the community participating in all the procedures and stages of the village finances, the government conducting supervision, and giving guidance through counseling and training for village officials. This study was also in line with Haning, et., al. (2018) and Fikri, et., al., (2018).

Ramly, et., al. (2018) analyzed the implementation of the village budget allocation policy and the village fund allocation which became second source in village finance revenue. The analysis made is to see how this village fund policy is able to increase the economic potency of the village so that there is equal distribution of income in village society. The method used is qualitative with descriptive analysis approach. The results of this study indicated that the policy of village funds and the allocation of village funds in the case of Kuala Sub district of Nagan Raya District still cannot increase the potential of the village through utilization village fund, while the potential of the village is very large. This is because the policy of village fund allocation is still directed to infrastructure development or physical potential, besides; there are still obstacles of human resources in managing the village funds. The same thing occurred in study of Kazimoto (2013) and Kuncoro, et al (2015).

Wicaksana, et. al. (2019) their research is to build a framework of public governance on Village Fund by implementing the efficient contracting, and to identify, illustrate and describe the variables in efficient contracting concept to Village Fund Management. The research used qualitative method, designed in narrative strategy and grounded theory approach, and formulated using constructivism paradigm. Results of the study have demonstrated that (1) Efficient contracting concept encompasses economic constitution, government policy, public finance management and governance, also the functional relationship in the government body (Central, Regional and Village); (2) the essence of Efficient Contracting is the community active participation, legal aspect, government attention, balance consensus, effectiveness and efficiency, justice and equality, transparency, responsibility and accountability (Fikri et., al., 2018).

Nurhakim and Yudianto (2018) study is to find out how the implementation of village fund management as well as supporting factors and inhibiting factors in the management of village funds. The method used in this research is a qualitative method with interview approach and observation with the responder in Soreang Village, Panyirapan Village, and Sukanagara Village. The results of this study indicate that the implementation of fund management from planning, implementation, administration, reporting, and accountability of the three villages are appropriate with the Regulation of the Minister of Home Affairs Number 113 the Year 2014 concerning Village Financial Management, but in terms of administration for the Panyirapan Village has not been in accordance with regulation, then for reporting the three villages have not been able to report to the 
regency in a timely manner based on regulations.

Mutolib, et. al. (2018) study aims to analyze the contribution of Village Funds in the development of BUMDes in Hanura Village, Teluk Pandan District, Pesawaran District, Lampung Province. The study used a qualitative descriptive approach. The results of this study indicate that village funds in Hanura Village have contributed to the development of BUMDes, there are 1) Market Management, 2) Product and Service Units, 3) Home Industry (Asni \& Budi, 2013).

Azlina, et. al. (2017) find the effectiveness of village funds management measured by target, on time, and responsibility of village management funds. This is a qualitative study with phenomenology methods. This study is performed at villages in coastal areas in Riau, in this case were villages in Bengkalis Regency. The results show that the village fund disbursed by the government to villages has been managed by almost the village villagers who have not been done by village development, there are still some needs of villagers who have not been touched by rural development, and In preparing this Report the village is not yet independent, still assisted by accounting personnel (Staff from the Districts) (Harrison, 2018; Hehamahua,2015).

\section{RESEARCH METHOD}

This study used a quantitative approach, the data is primary, collected through the distribution of questionnaires to a number of respondents (Creswell, 2018). Responden which have been selected purposively based on their knowledge and experience about the implementation of village fund program at Cimerang Village; consists of 12 Village Government Managers (Village Heads, Secretaries and Heads of Affairs), 10 Management of Village Community Empowerment Institutions (LPMD), 6 Managers of Village Consultative Body (BPD), 4 Management of Family Welfare Development (PKK), 5 Management of Youth Organization, as well as the community. Samples from the community in Cimerang village used random sampling; with a total population outside of Village Institution Board was 3,084 residents, and through Slovin formula, it was approached the figure was 96.85 ; so that the total Management and community sample were 133.85. To anticipate errors in filling and / or not returning, 150 questionnaires were distributed, and 135 were valid. In addition to distributing questionnaires, field observations were carried out to convince researchers of conditions in the Cimerang Village, such as limitation of health and education facilities, including access to locations.

Characteristics of the respondents as follows:

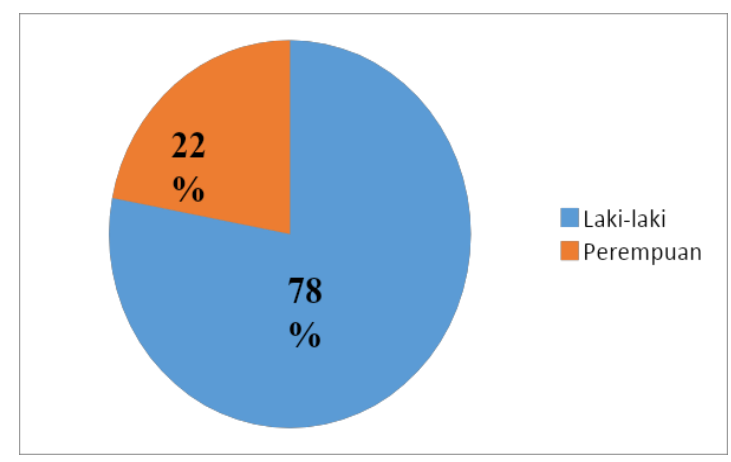

Figure 1. Respondents by Gender

Source: Google Form, 2019 (processed by author) 


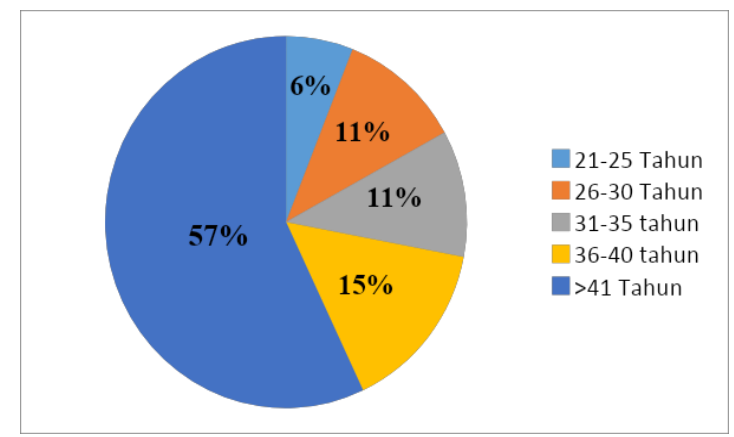

Figure 2. Respondents by Age

Source: Google Form, 2019 (processed by author)

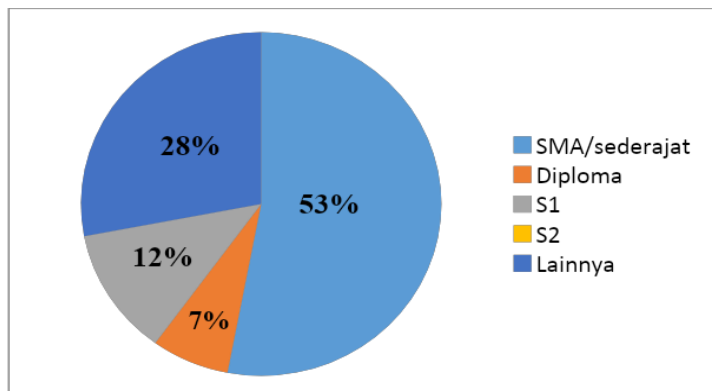

Figure 3. Respondents by Education Level

Source: Google Form, 2019 (processed by author)

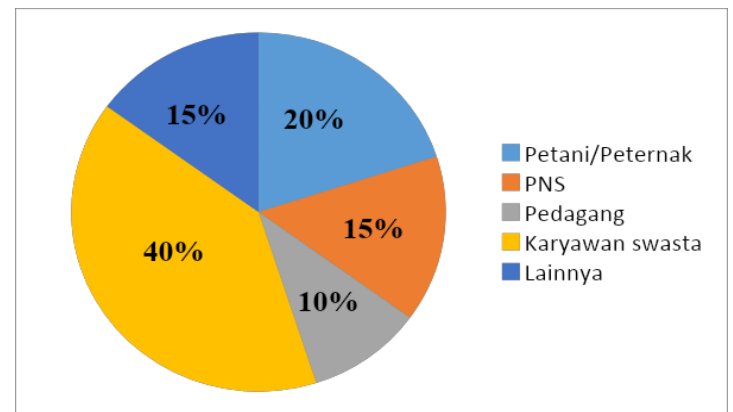

Figure 4. Respondents by Livelihood

Source: Google Form, 2019 (processed by author)

\section{RESULT AND DISCUSSION}

From data quality test on the questionnaire results from three independent variables and one dependent variable show all the questions are valid and reliable. Likewise, with the classical assumption test results, all variables are normally distributed (Figure 5), do not have multicollinearity problems (Table 1), and heteroskedasticity (Figure 6). 
Normal P-P Plot of Regression Standardized Residual

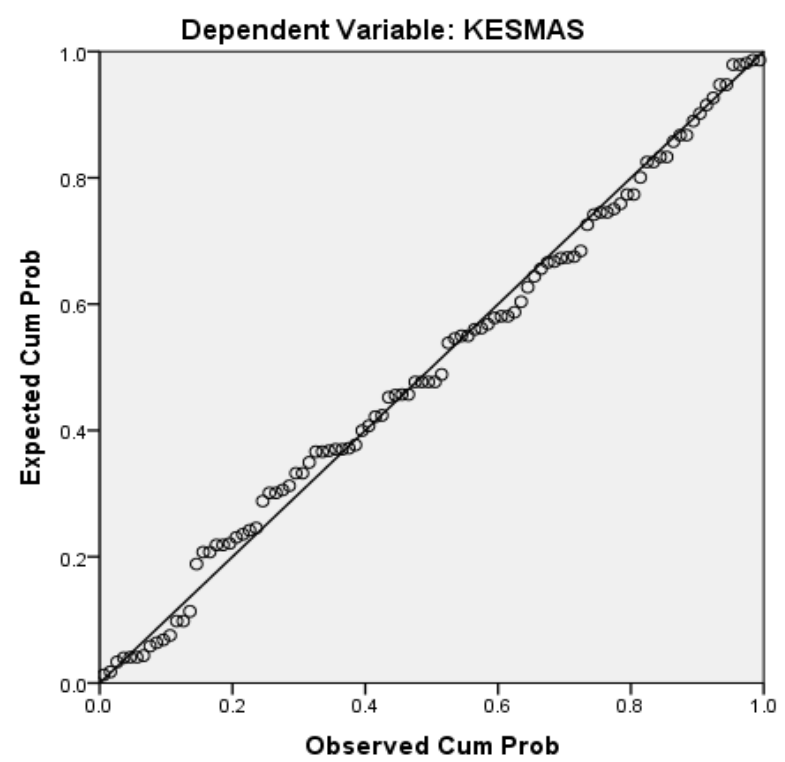

Figure 5. Normal P Plot of Regression Standardized Residual Source: SPSS, 2019 (processed by author)

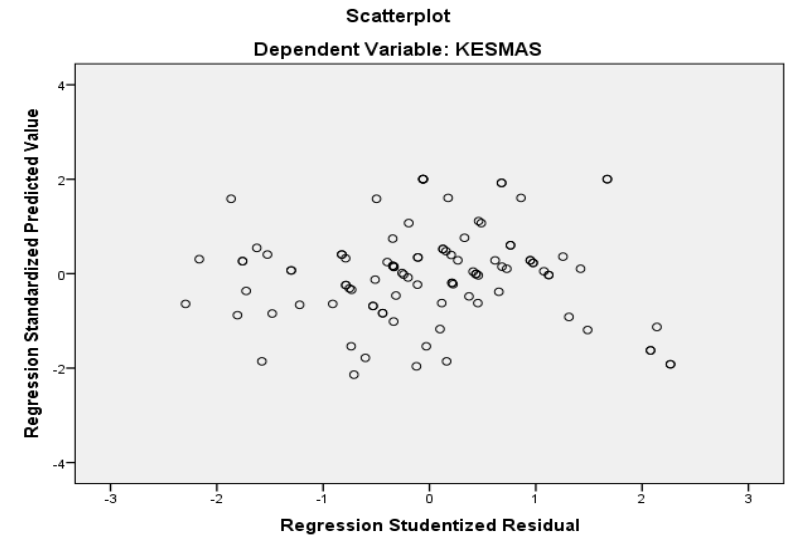

Figure 6. Heteroskedasticity Test Source: SPSS, 2019 (processed by author)

Hypothesis test results are presented in Table 1 and Table 2:

Table 1. The Result of Multiple Linear Regression Test

\begin{tabular}{|c|c|c|c|c|c|c|c|c|}
\hline & \multirow{3}{*}{ Model } & & & \multirow{3}{*}{$\begin{array}{c}\text { Coefficients } \\
\text { Standardized } \\
\text { Coefficients } \\
\text { Beta }\end{array}$} & \multirow{3}{*}{$\mathrm{t}$} & \multirow{3}{*}{ Sig. } & \multirow{2}{*}{\multicolumn{2}{|c|}{$\begin{array}{l}\text { Collinearity } \\
\text { Statistics }\end{array}$}} \\
\hline & & \multicolumn{2}{|c|}{$\begin{array}{l}\text { Unstandardized } \\
\text { Coefficients }\end{array}$} & & & & & \\
\hline & & B & $\begin{array}{l}\text { Std. } \\
\text { Error }\end{array}$ & & & & Tolerance & VIF \\
\hline \multirow{4}{*}{1} & (Constant) & 1.913 & .336 & & 5.692 & .000 & & \\
\hline & ACCT & 1.957 & 1.277 & 2.088 & 1.933 & .129 & .013 & 76.802 \\
\hline & VILLPOL & 1.236 & .636 & 1.499 & 1.944 & .055 & .013 & 76.802 \\
\hline & VILLINS & 1.201 & .668 & 1.382 & 1.797 & 0.75 & .013 & 76.802 \\
\hline
\end{tabular}

Source: SPSS, 2019 (processed by author) 
Purwanto, Hasna Safira

Determinant of Village Community Welfare Improvement

Table 2. The Result of $F$ Test

\begin{tabular}{|c|c|c|c|c|c|c|}
\hline \multicolumn{7}{|c|}{ ANOVA $^{a}$} \\
\hline & Model & Sum of Squares & $\mathrm{df}$ & Mean Square & $\mathrm{F}$ & Sig. \\
\hline \multirow{3}{*}{1} & Regression & 5.976 & 3 & 1.992 & 11.013 & $.000^{\mathrm{b}}$ \\
\hline & Residual & 17.365 & 96 & .181 & & \\
\hline & Total & 23.341 & 99 & & & \\
\hline
\end{tabular}

a. Dependent Variable: VILLWEL

b. Predictors: (Constant), ACCT, VILLPOL, VILLINS

Source: SPSS, 2019 (processed by author)

From the table above, the partial test result $(t$ test) demonstrated DD Financial Management Accountability had a significant effect on the improvement of Village Community Welfare ( $t$ count $>t$ table). This is confirmed by the result of scoring on the questionnaire distribution to the local community, getting good results at planning, implementation, and accountability stage. Note that the hope is consistency in its use must be in accordance with the plan; the use of DD has procedures that must be passed, namely in the planning stage, a hamletlevel discussion (MusDus) is held, then a village-level consultation (MusDes), then continues to make a Plan Budget (RAB). In the implementation phase, it must be in accordance with the agreed RAB. Furthermore, in the accountability stage an Accountability Report (LPJ) is made for reporting to the village head / sub-district head. The supervision process is carried out by an independent party, such as Babinsa (Bintara Pembina Desa), to prevent fraud or other undesirable things from happening. As villages in Banyuwangi Regency use technology of electronic governance to conduct innovation in supervising village financial management in order to be accountable and transparent. The innovations are electronic village budgeting and electronic monitoring system (Fikri, et.,al., 2018).

For village policies, the $t$ test also had a significant effect on improving the Village Community Welfare ( $t$ count $>t$ table). This policy is formally in the form of village regulations, structurally a form of follow-up and elaboration of higher regulations, as a sense of responsibility for village autonomy, remains under the authority and supervision of the city / district government. Nevertheless, the village has the right and authority to participate in determining the direction of national development in general and the development of the village itself specifically. It was confirmed from the results of an interview with Kasi Kesra, that the drafting process had gone through the stages of village-level deliberation and then village-level deliberations, then the results of the deliberations were mutually agreed upon and village officials poured them into village policy making; in it already contains policies that govern community development and empowerment. From the community members who were involved in the formulation of village policies, they thought that what they wanted was appropriate, even though the results of the policy had not been felt by all the people, only half of it. The factor could be due to insufficient distance, time, or funds. Law UU RI No. 6 (2014) concerning the implementation of BUMDes (VillageOwned Enterprises) is a breakthrough that needs to be considered by the Cimerang village community; as a reference is the success of DD like in Panggungharjo Village, Sewon District, Bantul Regency DIY; Majasari Village, Sliyeg Subdistrict, Indramayu Regency, West Java (Ministry of Finance Republic of Indonesia, 2017); Hanura Village, Teluk Pandan District, Pesawaran Regency, Lampung Province 
(Mutolib, et. al., 2019). From the examples above, a significant positive effect is increasing community participation, reducing unemployment, increasing welfare and becoming a sustainable, independent village. This is in line with the Government's plan to form 75,000 BUMDes (PDTT Village Minister Eko Putro Sandjojo, 2019). The third independent variable is the Village Institution, and from the test results, $\mathrm{t}$ count $>\mathrm{t}$ table, which means that it has a significant effect on Village Community Welfare. Scoring results from respondents obtained results with good categories in terms of performance, meaning that village institutions are indeed needed as a forum in serving the community. Although there is still a lack of natural resources or human resources, it does not mean village institutional tasks become weak. The Village Community Welfare can be interpreted as a social, material and spiritual procedure and livelihood which is encompassed by a sense of safety, decency, inner and outer tranquility.

Three indicators were used in this study: health, education and employment; based on the three indicators, the facts in the field and data are still far from the expectations of Cimerang village community, health services are not satisfactory, there are no public/ maternity clinics, Puskesmas, and pharmacies. Likewise, with the availabilityof educational facilities, only have elementary and junior high schools, as well as high unemployment rates (BPS KBB,2018).

\section{CONCLUSION AND SUGGESTION}

DD Financial Management Accountability, Village Policy, and Village Institution partially has a significant effect on the improvement of Village Community Welfare. To increase community trust and confidence in managing village funds, Cimerang village officials must carry out good governance, must be managed in an orderly manner, abiding by laws and regulations, transparent, accountable and participatory by taking into account the principles of justice, propriety, and benefits for rural communities.

The success of the development program can only be effective when all stakeholders participate in the program, from the beginning to the end, as is done by villages in Batang District, announcing their annual APBDes to their citizens so that there is no worry in the minds of the community; development of information technology systems through mobile phones in an effort to communicate between the apparatus and the village community; making non-permanent market facilities or utilizing existing vacant land and being used as vegetable or fruit gardens, building shop houses for later leased to others. Another suggestion is the preparation of a program in the formation of BUMDes, where the potential of Cimerang villages for agriculture, horticulture, and animal husbandry is still large to be explored and managed professionally, developed in the unity of tourist areas, involving the participation of village communities; There are no types of financial institutions such as KUD, BPR, Pegadaian, and this is an opportunity to berealized. From the results of BUMDes' efforts, the village will be more independent independently in improving the health and education sectors, for example by establishing a Polyclinic with diverse types of services, establishing a school equivalent to a high school / vocational school. The impact will be felt positively by the community, minimizing unemployment and increasing welfare.

This research was only conducted in one village. Therefore, the next researcher is expected to add other independent variables and the object of research to a wider scope of area. 


\section{REFERENCE}

Azlina, et. al. (2017). The Effectiveness of Village Fund Management (Case Study at Villages in Coastal Areas in Riau) (Vol 14, No. 12). International Journal of Economic Research.

Aziz, N.L.L. (2016). The Village Autonomy An The Effectiveness of Village Fund (Vol. 13, No. 2, pp193211). International Journal of Political Research.

Asni F, Maryunani, Sasongko, \& Dwi Budi. 2013. The Management of the Village Fund Allocation as an Instrument towards Economic Independence Village (Case Studies in 2 Village in Siak Regency, Riau Province (Vol 10, No. 4, pp. 1-9). International Journal of Business and Management.

Badan Pusat Statistik. (2018). Indikator Kesejahteraan Rakyat.

BPS Kabupaten Bandung Barat. (2018). Kecamatan Padalarang Dalam Angka.

Creswell, J. (2018). Research Design: Qualitative, Quantitative, and Mixed Methods Approaches. Fifth Edition. SAGE Publications Inc. Thousand Oaks California.

Deny, Septian. (2017). Ponggok Jadi Contoh Keberhasilan Pengelolaan Dana Desa. Retrieved from https://www.liputan6.com/bisnis/read /3068600/ponggok-jadi-contohkeberhasilan-pengelolaan-dana-desa

Dura, J. (2016). Pengaruh Akuntabilitas Pengelolaan Keuangan Alokasi Dana Desa, Kebijakan Desa, Dan Kelembagaan Desa Terhadap Kesejahteraan Masyarakat (Studi Kasus Pada Desa Gubugklakah Kecamatan Poncokusumo Kabupaten Malang) (Vol. 10, No.1, pp. 26-32). Jurnal JIBEKA.

Fiansyah, Rahmat. (2019). Dulu Miskin, Desa Kutuh Bali Jadi Destinasi Wisata Olahraga Berkat Dana Desa. Retrieved from https://www.inews.id/finance/makro/ dulu-miskin-desa-kutuh-bali-jadidestinasi-wisata-olahraga-berkatdana-desa?page $=$ all.

Fikri H, Didik Gunawan Suharto, \& Rino Ardhian Nugroho. (2018). Utilization of Electronic Government in Realizing Transparency and Accountability of Village Government: Sinergy of Implementation of Electronic Village Budgeting and Electronic Monitoring System by Banyuwangi Government (Vol 5, No. 4, pp. 453-469). International Journal of Multicultural and Multireligious Understanding,.

Fourchard, L. (2011). Between world history and state formation: New Perspectives on Africa's Cities (Vol. 52, pp. 223-48). International Journal of African History.

Haning, M. T. \& Mashuri H. Tahili. (2018). Strengthening the Capacity of Village Government in the Implementation of Village Fund Policy at Maros Regency of South Sulawesi Province (Vol 191, pp. 383391). Advances in Social Science, Education and Humanities Research.

Harrison, G. (2008). From the Global to the Local? Governance and Development at the Local Level: Reflections from Tanzania (Vol 46, No. 2, pp. 169-189). International Journal of Modern African Studies.

Hehamahua, H. (2015). Impact Analysis of the Village Fund Allocation Toward Economic Community (Case Study on the Rural District of Namlea Siahoni, Buru Regency) (Vol. 6, No.3, pp. 1523). International Journal of Social and Development Sciences,

Kazimoto, P. (2013). Assessment of Villages Financial Management Challenges and Development Strategies in Tanzania, Arumeru District (Vol 3, No.2, pp. 112-118). International Journal of Research in Social Sciences. 
Kementrian Keuangan Republik Indonesia. (2017). Buku Pintar Dana Desa-Dana Desa untuk Kesejahteraan Rakyat.

Kementrian Keuangan Republik Indonesia. (2017). Retrieved from https://www.kemenkeu.go.id/media/6 749/buku-pintar-dana-desa.pdf

Kementrian Keuangan Republik Indonesia. (2020). Retrieved from https://lokadata.id/data/anggarandana-desa-2015-2020-1565947501

Kuncoro A, Grahita Candrarin, \& Sudarman. (2015). Supervision Contributes for Success of Megawon Village Fund Program Jati District Kudus Regency Central Java Indonesia by Using Good Governance a Contingency Variable (Vol 5, No.9, pp. 4974-4977). The International Journal of Social Sciences and Humanities Invention.

Mutolib, et. al. (2018). Kontribusi Dana Desa dalam Pengembangan Badan Usaha Milik Desa di Desa Hanura, Kabupaten Pesawaran, Provinsi Lampung (Vol. 3, No. 1). JSHP.

Nasution et. al. (2017). The Role of Village Funds to the Development Area in the Sub District of West Bilah, Labuhanbatu Regency, North Sumatera, Indonesia (Vol. 6, No. 1, pp. 221-227). International Journals of Sciences and High Technologies.

Novianti, et. al. (2017). Analisis Penerapan Alokasi Dana Desa (ADD) Dalam Upaya Meningkatkan Pembangunan Desa (Studi Kasus Pada Desa Suwaan, Kecamatan Kalawat, Kabupaten Minahasa Utara) (Vol. 12, No. 1, pp 83-90), Jurnal Riset Akuntansi Going Concern.

Nurhakim \& Yudianto. (2018). Implementation of Village Fund Management (Vol. 1, No. 2). International Journal of Accounting Auditing and Business.

Peraturan Menteri Dalam Negeri No.113.
(2014). Tentang Pengelolaan Keuangan Desa.

Peraturan Menteri Keuangan Republik Indonesia No. 205/PMK.07. (2019). Tentang Pengelolaan Dana Desa.

Peraturan Pemerintah Republik Indonesia No.60. (2014). Tentang Dana Desa Yang Bersumber Dari APBN.

Permendesa PDTT No. 11. (2019). Tentang Prioritas Penggunaan Dana Desa Tahun 2020.

Rakyat Merdeka. (2019). Menteri Desa Target Dirikan 75 Ribu BUMDes. Retrieved from https://rmco.id/bacaberita/governmentaction/9393/menteri-desa-targetdirikan-75-ribu-bumdes

Ramly, A., Wahyuddin, Julli Mursyida, \& Mawardati. (2018). The Implementation of Village Fund Policy in Improving Economy of Village Society (Case Study at Kuala Sub District of Nagan Raya District) (Vol. 6, No. 3, pp. 459-478). The International Journal of Social Sciences.

Robinson. (2013). The Urban Now: Theorising Cities Beyond The New. Sage International Journal

Savitri, et. al. (2019). Accountability of Village Funds Management. Journal of Applied Management (JAM) (Vol. 17, No. 3). Indexed in Google Scholar.

Syafi'i, et. al. (2018). Pengaruh Akuntabilitas Pengelolaan Keuangan ADD, Kebijakan Desa, dan Kelembagaan Desa terhadap Pemberdayaan Masyarakat (Vol. 7, No. 2). E-JRA.

Temenggung, Y. (2014). Rural Financial Management in Perspective Law No.6 of 2014 Concerning The Village (Vol 43, No.1, pp 42-54). International Journal of Social Sciences.

Times Indonesia. (2019). Retrieved from https://www.viva.co.id/berita/nasional /1148475-pujon-kidul-jadi-contohkeberhasilan-pengelolaan-dana-desa 
Todaro, P. M., \& Stephen. C. S. (2006). Pembangunan Ekonomi. Jakarta: Penerbit Erlangga.

Undang-Undang Republik Indonesia Nomor 6. (2014). Tentang Desa.

Wibisono, Nurharibnu, \& Herry Purnomo. (2017). Public Participation on Village Fund Monotoring in Madiun Regency, Indonesia (Vol 7, No.10, pp. 124-129). Developing Country Studies.

Winarsih, Sri, \& Dwi Rahayu Kristianti. (2017). Village Fund Management in the Perspective of State Finances for the Purpose of Rural Community Empowerment (Vol. 131, pp. 277281). Advances in Social Sciences, Education and Humanities Research.

Waluyo. (2007). Manajemen Publik (Konsep, Aplikasi dan Implementasi Dalam Pelaksanaan Otonomi Daerah). Bandung: Mandar Maju.

Wicaksana, et. al. (2019). The Regulation on Village Governance in Indonesia: Efficient Contracting in Agency Theory (Vol. 9, No. 2). Journal of Public Administration and Governance. 